\title{
Occurrence of larvae of trypanorhynch cestodes in snappers (Lutjanidae) from northeast Brazil
}

\author{
Ocorrência de larvas de cestodas trypanorhyncha em vermelhas (Lutjanidae) do nordeste do Brasil \\ André Mota Alves ${ }^{1 *}$; Geza Thais Rangel e Souza ${ }^{2}$; Ricardo Massato Takemoto ${ }^{3}$; Luiz Eduardo Roland Tavares ${ }^{4}$; \\ Cláudia Moura de Melo ${ }^{1}$; Rubens Riscala Madi ${ }^{1}$; Verónica de Lourdes Sierpe Jeraldo ${ }^{1}$

\begin{abstract}
${ }^{1}$ Laboratório de Biologia Tropical, Instituto de Tecnologia e Pesquisa - ITP, Universidade Tiradentes - UNIT, Aracaju, SE, Brasil
${ }^{2}$ Instituto Federal de Educação, Ciência e Tecnologia de São Paulo - IFSP, Avaré, SP, Brasil

${ }^{3}$ Núcleo de Pesquisas em Limnologia, Ictiologia e Aquicultura, Laboratório de Ictioparasitologia, Universidade Estadual de Maringá UEM, Maringá, PR, Brasil

${ }^{4}$ Centro de Ciências Biológicas e da Saúde, Universidade Federal do Mato Grosso do Sul - UFMS, Campo Grande, MS, Brasil
\end{abstract}

Received January 9, 2018

Accepted January 29, 2018

\begin{abstract}
Three species of snappers from artisanal, small-scale fisheries were examined for the presence of parasites. A total of 139 lutjanid fish were collected: 69 specimens of Lutjanus analis, 47 specimens of Lutjanus vivanus, and 23 specimens of Lutjanus synagris. Encysted plerocercoid of trypanorhynch cestodes found at necropsy in the viscera of snappers were sampled for parasitological analysis. These plerocercoid larvae belong to the genera Floriceps, Pseudogrillotia, and Oncomegas. Although these parasites do not have any zoonotic potential, fish with heavy loads of plerocercoids are rejected during inspection as they compromise meat hygiene. Our findings suggest that light larval cestode infections in lutjanids would not lead to consumer rejection of the food product. The occurrence of Floriceps sp. in L. analis and in L. synagris, of Pseudogrillotia sp. in L. vivanus and in L. synagris, and of Oncomegas sp. in L. synagris are new findings in these fish species. These parasites are new to these fish species and have not been reported in snappers from the northeast coast of Brazil. The results contribute to the existing body of knowledge about the parasitic fauna of fish and its distribution along the coastline of Brazil.
\end{abstract}

Keywords: Fish, Lutjanus, parasites, Floriceps, Oncomegas, Pseudogrillotia.

\section{Resumo}

Três espécies de pargos de pescaria artesanal e de pequena escala foram examinadas quanto à presença de parasitas. Um total de 139 peixes lutjanídeos foram coletados: 69 espécimes de Lutjanus analis, 47 de Lutjanus vivanus e 23 de Lutjanus synagris. Cistos de plerocercóides de cestodas Trypanorhyncha encontrados durante a necrópsia nas vísceras de pargos foram amostrados para análise parasitológica. Estas larvas plerocercóides pertencem aos gêneros Floriceps, Pseudogrillotia e Oncomegas. Embora esses parasitas não tenham qualquer potencial zoonótico, peixes com elevadas cargas de plerocercóides são rejeitados durante a inspeção, pois comprometem a higiene da carne. Os achados sugerem que baixas infecções por essas formais larvais de cestodas em lutjanídeos não levariam a rejeição do consumidor quanto ao produto alimentar. A ocorrência de Floriceps sp. em L. analis e em L. synagris, de Pseudogrillotia sp. em L. vivanus e em L. syngaris, e de Oncomegas sp. em L. synagris são novas descobertas nestas espécies de peixes. Estes parasitas são novos para essas espécies de peixes e náo foram relatados em pargos da costa nordeste do Brasil. Os resultados contribuem para o conhecimento existente sobre a fauna parasitária do peixe e sua distribuição ao longo do litoral do Brasil.

Palavras-chave: Peixe, Lutjanus, parasitas, Floriceps, Oncomegas, Pseudogrillotia.

In Brazil, artisanal fishermen harvest several species of reef fish including red snappers which belong to the Family Lutjanidae, Order Perciformes. Lutjanids are cosmopolitan, generalist, carnivorous

*Corresponding author: André Mota Alves. Laboratório de Biologia Tropical, Instituto de Tecnologia e Pesquisa - ITP, Universidade Tiradentes - UNIT, Rua de Riachão, Bairro Cirurgia, 970, CEP 49055-600, Aracaju, SE, Brasil. e-mail: andremta@outlook.com fish, and are of great economic importance in the market. Tropical and subtropical regions host more than 17 genera and 110 valid species of snappers; 15 species of lutjanids are extensively exploited in northeast Brazil (FRÉDOU \& FERREIRA, 2005; BEGOSSI et al., 2011); the Mutton snapper - Lutjanus analis (Cuvier, 1828), the Silk snapper - Lutjanus vivanus (Cuvier, 1828), and the Lane snapper - Lutjanus synagris (Linnaeus, 1758) 
are just three of the many fish species that are found along the coastal strip of Northeast Brazil and also in the State of Sergipe in the Northeast Region of the country. Fish from this particular family have a generalist diet and are, therefore, exposed to a wide range of parasites including cestodes of the Order Trypanorhyncha (Diesing, 1863) which have a global distribution. Adult forms of these flatworms infect definitive hosts which are elasmobranchs (sharks and rays) whereas larval stages of these parasites often occur in teleosts (EIRAS et al., 2010; SILVA \& GAMA, 2010). The purpose of this study was to investigate the parasitic fauna of lutjanid fish from northeast Brazil which remains unknown.

We report novel host species harboring larval forms of Trypanorhyncha in new geographic locations in this particular region of the country. The species of fish used in this study were restricted to the Western Atlantic, in the American coast. Fish were purchased on a monthly basis between March 2015 and October 2016 at a municipal fishing port in Aracaju (capital of the State of Sergipe in Northeast Brazil) (1054'17'S37²'56”W) depending on product availability. Fish bought from artisanal fishermen working along Brazil's northeastern coast were sent to our research laboratory at a local university (UNIT - Tiradentes University, Aracaju, SE, Brazil) where they were identified at the species level. Total length, weight, and pattern of fish specimens were recorded, and parasitological analysis was conducted according to the technique published by Eiras et al. (2006). Parasitic larval stages were stained with hydrochloric carmine and mounted onto glass slides using Canada balsam. Prevalence (P) in percentage and mean intensity (MI) of parasites were measured according to guidelines from a publication authored by Bush et al. (1997).

Permanent mounts of these parasites were deposited in the zoological collection of the Federal University of Mato Grosso do Sul (UFMS), Campo Grande, MS, Brazil; 69 specimens of L. analis (average length of $30.47 \mathrm{~cm}$ and average weight of $418.20 \mathrm{~g}$ ), 47 specimens of L. vivanus (average length of $30.68 \mathrm{~cm}$ and average weight of $336.74 \mathrm{~g}$ ), and 23 specimens of $L$. synagris (average length of $29.67 \mathrm{~cm}$ and average weight of $438.86 \mathrm{~g}$ ) were examined for the presence of parasites; the fish examined were approximately $30 \mathrm{~cm}$ long, according to Allen (1985) fish in this average length are already sexually mature; 7 tissue cysts (plerocercoids) were collected at necropsy from viscera of these fish: 2 cysts from $L$. analis (one was attached to the gills and the other to the mesentery), 2 cysts from $L$. vivanus (one attached to the mesentery and the other attached to the gonads), and 3 cysts from L. synagris (one was attached to the epicardial surface, one to the liver, and one to the gills). Plerocercoid larvae were sampled from ruptured cysts. These specimens were identified as plerocercoids of the genus Floriceps (Cuvier, 1917), Pseudogrillotia (Dollfus, 1969), and Oncomegas (Dollfus, 1929), according to identification keys to cestode parasites of vertebrates published by Khalil et al. (1994). The parasites were found in April and July 2015, and October 2016, different periods for the three species of fish. Below, we describe the morphological features of each of the collected specimens.

Trypanorhyncha Diesing, 1863

Lacistorhynchidae Guiart, 1937

Floriceps Cuvier, 1817 (Figure 1)

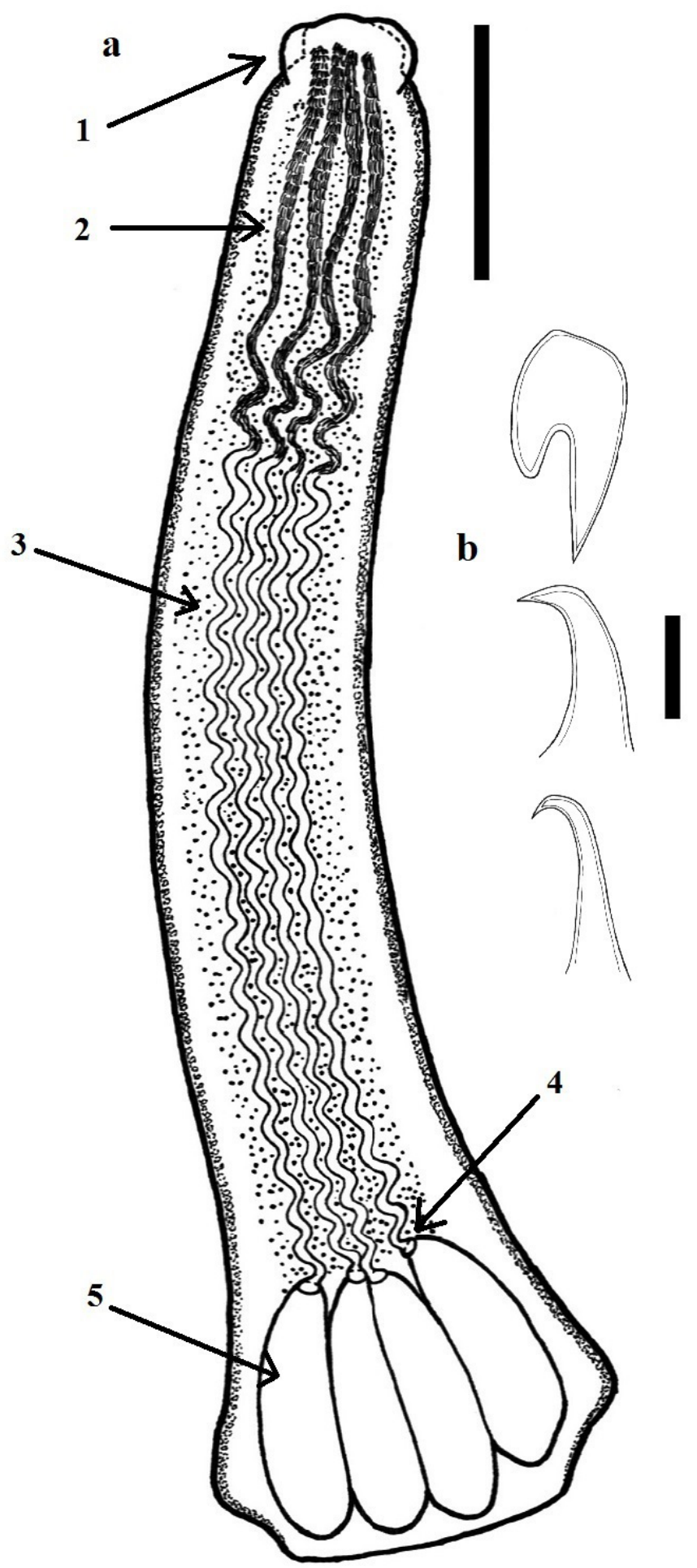

Figure 1. (a) Floriceps sp. larva collected from cysts found in specimens of Lutjanus analis and Lutjanus synagris. 1- Anterior region with two bothridia; 2- Tentacles with retracted hooks; 3- Tentacle sheaths; 4- retractor muscles; 5- Pars bulbosa. Scale bar: $1 \mathrm{~mm}$; (b) Heteromorphic hooks. Scale bar: $0.01 \mathrm{~mm}$.

Detailed description of the parasite morphology: plerocercoid larvae. Elongated, wide body (body length: $6.1 \mathrm{~mm}$; widest body portion: $1.5 \mathrm{~mm}$ ). Scolex bothridial, and has 2 indented bothridia in the posterior margin (length: $0.2 \mathrm{~mm}$, width: $0.07 \mathrm{~mm}$ ). 
The pars vaginalis is long $(4.4 \mathrm{~mm})$. There are 4 hooked tentacles at the anterior (cranial) extremity of the parasite's body that can be either extended or retracted through 4 apertures (length: $1.7 \mathrm{~mm}$ which is the area occupied by the tentacles when they are entirely retracted within the parasite body). Each tentacle has a spiral sheath connected to retractor muscles which are attached to paired bulbs (length: $1.2 \mathrm{~mm}$ ) that assist in tentacle protrusion. The post-bulbous region is absent. Heteromorphic hooks.

Hosts: L. analis and L. synagris.

Geographic location: Northeast coast, Aracaju, SE, Brazil.

Parasitic indices: $\mathrm{P}-$ L. analis $=2.89 \%$, L. synagris $=4.34 \%$; $\mathrm{MI}-$ L. analis $=1.00 ;$ L. synagris $=1.00$

Sites (affected organs and tissues): L. analis - cysts in víscera and gills; L. synagris - a cyst on the epicardial surface.

Specimens deposited at: ZUFMS - PLA00014.

Zoology collection of the Federal University of Mato Grosso do Sul (UFMS), Campo Grande, Mato Grosso do Sul, Brazil.

Lacistorhynchidae Guiart, 1937

Pseudogrillotia Dollfus, 1969 (Figure 2)

Detailed description of the parasite morphology: plerocercoid larvae. Elongated body, longer than wide (length: $10.6 \mathrm{~mm}$, width: $0.8 \mathrm{~mm}$ ). Scolex bothridial, anterior (cranial) region with two prominent bothridia (length: $0.68 \mathrm{~mm}$, width: $0.15 \mathrm{~mm}$ ). These structures are provided with 4 apertures, and 4 hooked tentacles protrude and retract through these openings (length: $3.6 \mathrm{~mm}$ ). The pars vaginalis is long (length: $2.8 \mathrm{~mm}$ ). Tentacles have spiral sheaths that are connected to bulbs which are longer than wide (length: $0.9 \mathrm{~mm}$; width: $0.26 \mathrm{~mm}$ ). A post-bulbous region is present; it is elongated, sharpened at the posterior end, larger than the pars vaginalis, and has more than half of the total length of the parasite body (length: $6.0 \mathrm{~mm}$ ). Heteromorphic hooks.

Hosts: L. vivanus and L. synagris.

Geographic location: Northeast coast, Aracaju, SE, Brazil

Parasitic indices: $\mathrm{P}-$ L. vivanus $=4.25 \%$, L. synagris $=4.34 \%$;

$\mathrm{MI}-$ L. vivanus $=1.00$, L. synagris $=1.00$

Sites (affected organs and tissues): L. vivanus - mesentery and gonads; L. synagris - mesentery.

Specimens deposited at: ZUFMS - PLA00015.

Zoology collection of the Federal University of Mato Grosso do Sul (UFMS), Campo Grande, Mato Grosso do Sul, Brazil.

Eutetrarhynchidae Guiart, 1927

Oncomegas Dollfus, 1929 (Figure 3)

Detailed description of the parasite morphology: plerocercoid larvae. Slender body, longer than wide (length: $2.9 \mathrm{~mm}$; width: $0.5 \mathrm{~mm}$ ). Scolex bothridial, anterior (cranial) region of the parasite has two prominent bothridia (length: $0.46 \mathrm{~mm}$, width: $0.36 \mathrm{~mm}$ ). Thorned tentacles protrude through apertures located at the anterior (cranial) region of the parasite. The pars vaginalis is long (length: $1.2 \mathrm{~mm}$ ). The pars bulbosa has 4 long, broad bulbs (length: $1.1 \mathrm{~mm}$, width: $0.07 \mathrm{~mm}$ ). Tentacles have a basal undulation, a swelling, and a single macrohook (length: $0.02 \mathrm{~mm}$ ) located in the basal region of each tentacle, and this is a main distinguing morphological feature of the genus Oncomegas. Length: $1.1 \mathrm{~mm}$ which corresponds to the area occupied by these appendages when retracted within the parasite body. The post bulbosa region is absent. Heteromorphic hooks.

Host: L. synagris.

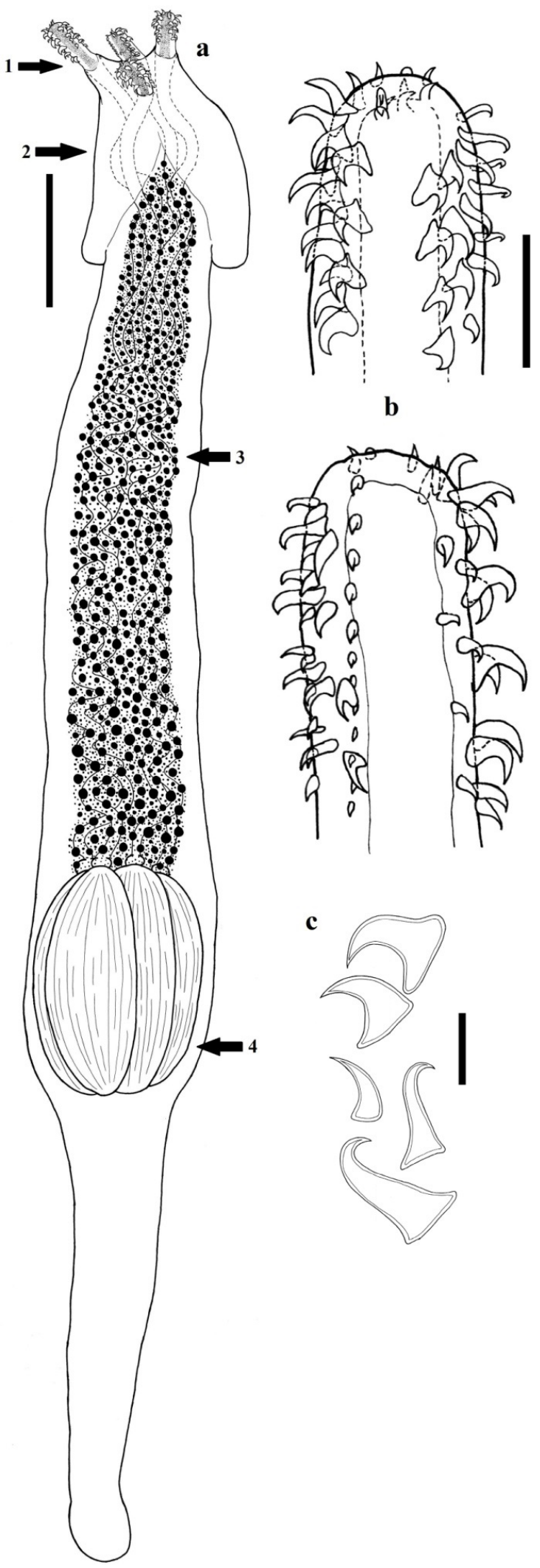

Figure 2. Pseudogrillotia sp. larva collected from cysts found in specimens of Lutjanus analis and Lutjanus synagris. (a) Entire body of the parasite: 1- Partially extruded tentacles; 2- Anterior region with two bothridia; 3-Pars vaginalis; 4- Pars bulbosa. Scale bar: $1 \mathrm{~mm}$; (b) Detail of the apex of a hooked tentacle. Scale bar: $0.05 \mathrm{~mm}$; (c) Heteromorphic hooks. Scale bar: $0.01 \mathrm{~mm}$. 


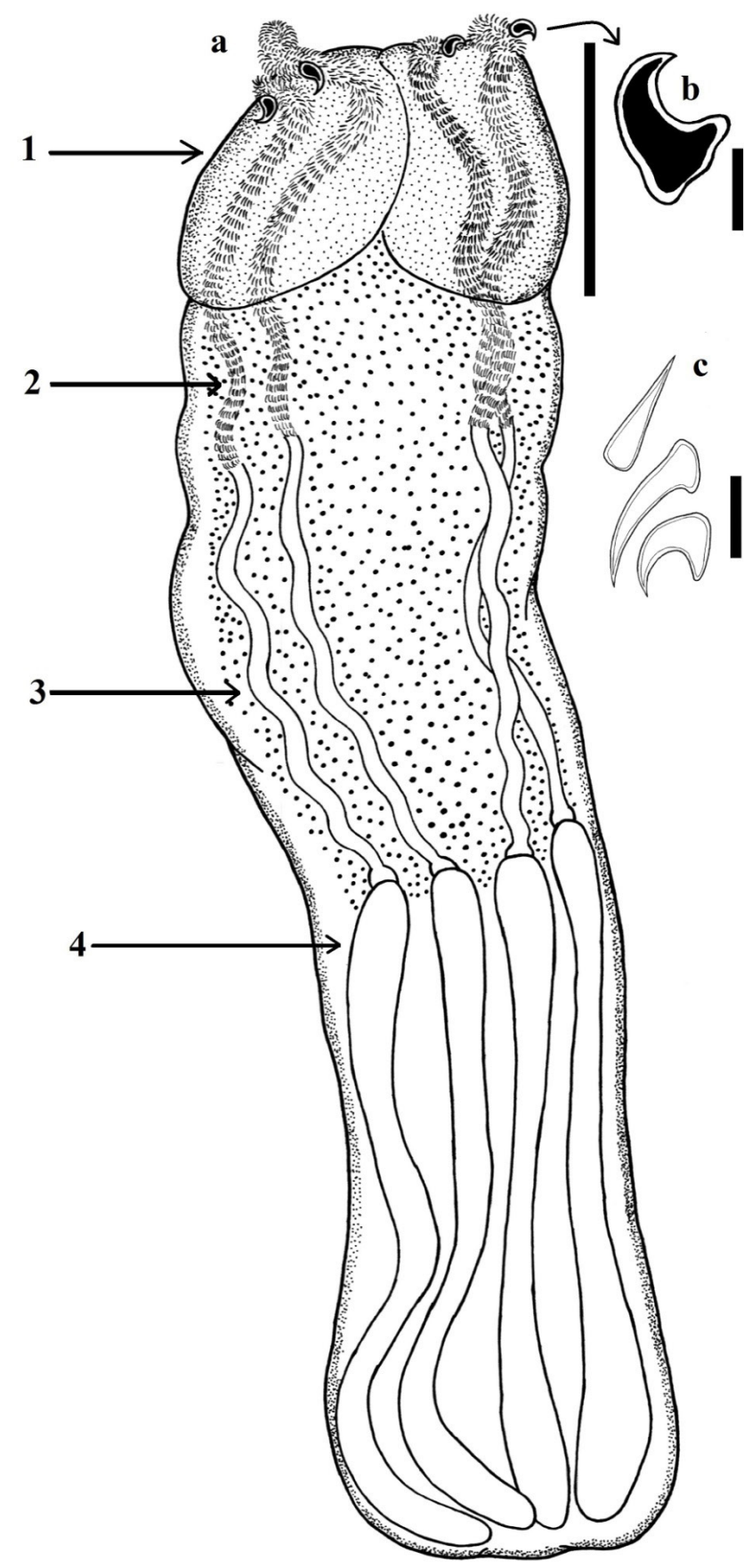

Figure 3. (a) Oncomegas sp. larva collected from Lutjanus synagris. Scale bar: $0.5 \mathrm{~mm}$. 1-Anterior region with two bothridia; 2- Tentacles with hooks; 3-Tentacle sheaths; 4- Pars bulbosa. (b) Detail of a basal hook. Scale bar: $0.01 \mathrm{~mm}$; (c) Heteromorphic hooks. Scale bar: $0.01 \mathrm{~mm}$.

Geographic location: Northeast coast, Aracaju, SE, Brazil.

Parasitic indices: P - 4.34\%; MI - 1.00

Sites (affected organs and tissues): a single cyst was found attached to the gills.

Specimens deposited at: ZUFMS - PLA00016.

Zoology collection of the Federal University of Mato Grosso do Sul (UFMS), Campo Grande, Mato Grosso do Sul, Brazil.

The most recent record of Trypanorhyncha (Lutjanidae) was published by Haseli et al. (2011). These researchers studied the fauna of this particular group of cestodes in teleosts from the Persian Gulf, Iran, and found Floriceps sp. in Lutjanus coccineus, L. fulviflamma, and L. kasmira. Beveridge et al. (2014) detected plerocercoid of Callitetrarhynchus gracilis, Pseudobothrium dipsacum, and Pseudolacistorhynchus heroniensis (Trypanorhyncha) in L. carponotatus, L. gibbus, and L. vitta, but did not find any larval stages from the genus Floriceps, Pseudogrillotia, or Oncomegas in these species of the Family Lutjanidae (snappers). Hermida et al. (2014) examined specimens of $L$. analis from the State of Alagoas, northeast Brazil. The authors, however, did not specify the family or genus of Trypanhorhyncha found in this particular species of lutjanid fish. The genus Oncomegas, order Trypanorhyncha, is characterized by the presence of a single macrospine in the basal region of the tentacles (SCHAEFFNER \& BEVERIDGE, 2012). To date, there are a scant number of publications about Oncomegas infestation in fish, and only a few species of cestodes belong to this genus. The majority of the cases of Oncomegas infection have been reported in elasmobranchs which were found to be parasitized with adult tapeworms. A checklist published by Schaeffner \& Beveridge (2014) records the occurrence of Oncomegas in Dasyatidae (whiptail stingrays). Larval forms of $O$. wageneri were found in Syacium gunteri (Shoal flounders) from the Gulf of Mexico by Vidal-Martínez et al. (2015). To the best of our knowledge, there are no reports of Oncomegas or Pseudogrillotia infestation in lutjanid fish. Although not zoonotic, heavy cestode infections can have a negative impact on the commercialization of the product as it affects the quality and aesthetic appearance of fish leading to carcass rejection (SÁO CLEMENTE et al., 2004). The occurrence of Floriceps sp. in L. analis and in L. synagris, of Pseudogrillotia sp. in L. vivanus and in L. synagris, and of Oncomegas sp. in L. synagris are new findings in these fish species, and have not been reported in snappers from the Northeast coast of Brazil. A double infection was observed by one Floriceps larva and one of Oncomegas in a specimen of L. synagris. The results of our study contribute to a growing literature on the parasitic fauna of fish and on the geographic distribution of these parasites along the Brazilian coastline.

\section{References}

Allen GR. FAO species catalog. Rome: FAO Fisheries Synopsis; 1985 Vol. 6 - Snappers of the world: an annotated and illustrated catalogue of lutjanid species known to date, no. 125.

Begossi A, Salivonchyk SV, Araujo LG, Andreoli TB, Clauzet M, Martinelli $\mathrm{CM}$, et al. Ethnobiology of snappers (Lutjanidae): target species and suggestions for management. J Ethnobiol Ethnomed 2011; 7(1): 11. http:// dx.doi.org/10.1186/1746-4269-7-11. PMid:21410969.

Beveridge I, Bray R, Cribb TH, Justine JL. Diversity of Trypanorhynch metacestodes in teleost fishes from coral reefs off eastern Australia and New Caledonia. Parasite 2014; 21(60): 1-19. http://dx.doi.org/10.1051/ parasite/2014060. PMid:25402635.

Bush AO, Lafferty KD, Lotz JM, Shostak AW. Parasitology meets ecology on its own terms: Margolis et al. revisited. J Parasitol 1997; 83(4): $575-$ 583. http://dx.doi.org/10.2307/3284227. PMid:9267395.

Eiras JC, Takemoto RM, Pavanelli GC. Métodos de estudo e técnicas laboratoriais em parasitologia de peixes. Maringá: Eduem, 2006. 
Eiras JC, Takemoto RM, Pavanelli GC. Diversidade dos parasitas de peixes de água doce do Brasil. Maringá; Clichetec; 2010.

Frédou T, Ferreira BP. Bathymetric trends of northeastern Brazilian snappers (Pisces, Lutjanidae): implications for the reef fishery dynamic. BrazArch Biol Technol 2005; 48(5): 787-800. http://dx.doi.org/10.1590/ S1516-89132005000600015.

Haseli M, Malek M, Valinasab T, Palm WH. Trypanorhynch cestodes of teleost fish from the Persian Gulf, Iran.J Helminthol 2011; 85(2): 215224. http://dx.doi.org/10.1017/S0022149X10000519. PMid:20825688.

Hermida M, Carvalho BFL, Cruz C, Saraiva A. Parasites of the mutton snapper Lutjanus analis (Perciformes: Lutjanidae) in Alagoas, Brazil. Rev Bras Parasitol Vet 2014; 23(2): 241-243. http://dx.doi.org/10.1590/ S1984-29612014023. PMid:25054505.

Khalil LF, Jones A, Bray RA. Keys to the cestode parasites of vertebrates. Wallingford: Cab International; 1994.

São Clemente SC, Knoff M, Padovani RES, Lima FC, Gomes DC. Cestóides Trypanorhyncha parasitos de Congro-rosa, Genypterus brasiliensis
Regan, 1903 comercializados nos municípios de Niterói e Rio de Janeiro, Brasil. Rev Bras Parasitol Vet 2004; 13(3): 97-102.

Schaeffner BC, Beveridge I. Description of a new Trypanorhynch species (Cestoda) from Indonesian Borneo, with the suppression of Oncomegoides and the erection of a new genus Hispidorhynchus. J Parasitol 2012; 98(2): 408-414. http://dx.doi.org/10.1645/GE-2859.1. PMid:22032262.

Schaeffner BC, Beveridge I. The Trypanorhynch cestode fauna of Borneo. Zootaxa 2014; 3900(1): 21-49. http://dx.doi.org/10.11646/ zootaxa.3900.1.2. PMid:25543722.

Silva ACS Jr, Gama CDS. Parasitismo por cestoides da ordem Trypanorhyncha na musculatura de Plagioscion squamosissimus - pescada branca (Perciforme: Sciaenidae), comercializados em Macapá, AP. Cienc Anim Bras 2010; 11(3): 737-742. http://dx.doi.org/10.5216/cab.v11i3.8495.

Vidal-Martínez VM, Torres-Irineo E, Romero D, Gold-Bouchot G, Martínez-Meyer E, Valdés-Lozano D, et al. Environmental and anthropogenic factors affecting the probability of occurrence of Oncomegas wageneri (Cestoda: Trypanorhyncha) in the southern Gulf of Mexico. Parasit Vectors 2015; 8(1): 609. http://dx.doi.org/10.1186/s13071-0151222-6. PMid:26610603. 